\title{
КЛІНІЧНЕ ЗНАЧЕННЯ ТЕРМОГРАФІЇ ПРИ ХРОНІЧНОМУ ПОДАГРИЧНОМУ АРТРИТІ
}

\author{
๑С. М. Андрейчин, У. О. Мудра, Т. Ю. Чернець
}

Тернопільський національний медичний університет імені І. Я. Горбачевського МОз України

РЕЗЮМЕ. В останні роки значно підвищився інтерес до вивчення подагри у зв'язку з високим рівнем захворюваності на цю патологію та частими рецидивами, що приводять до тривалої втрати працездатності. До важливих клініко-патогенетичних проявів подагри належать порушення терморегуляції та реґіонарного кровотоку. Разом з тим, термографія подагричного артриту залишається мало вивченою.

Мета дослідження - клініко-патогенетичне обґрунтування можливого застосування термографії для розпізнавання хронічного подагричного артриту.

Матеріал і методи. У дослідження включено 40 стаціонарних пацієнтів з хронічним подагричним артритом (37 чоловіків і 3 жінки) віком від 45 до 74 років. Тривалість захворювання склала понад 5 років. Термографічне дослідження здійснювали за допомогою тепловізора ULIRvision TI 120 (Zhejiang Ulirvision Technology Co., Китай), дотримуючись рекомендацій виробника.

Результати. Встановили, що зі зростанням тривалості захворювання збільшується число уражених суглобів, тофусів, збільшуються інтенсивність болю за ВАШ, частота загострень протягом року. На термограмах, отриманих у фазі загострення хронічного подагричного артриту, видно зону інтенсивної гіпертермії, яка за розмірами перевищувала видиму гіперемію. Границі еритеми чіткі. $\Delta$ Т дорівнювала $1,8-5,4{ }^{\circ} \mathrm{C}$. У реконвалесцентів при виписуванні зі стаціонару зона гіпертермії мала менші площу й інтенсивність, чіткість контурів втрачалася. $\Delta$ T склала 0,7-3,3 ${ }^{\circ} \mathrm{C}$. Через 2 місяці після виписування у більшості хворих зберігалася гіпертермія невеликої інтенсивності над досліджуваним суглобом. $\Delta$ Т становила $0,6-1{ }^{\circ} \mathrm{C}$.

Висновки. При подагричному артриті у фазі загострення наявне інтенсивне інфрачервоне випромінювання 3 ураженої ділянки. На термограмах воно проявляється термоасиметрією, із зоною гіпертермії, яка перевищує площу запалення. У фазі загострення цього захворювання перепад радіаційної температури у вогнищі запалення, порівняно із симетричними здоровими ділянками шкіри, коливається від 1,8 до 5,4 ${ }^{\circ} \mathrm{C}$. У період ремісії хронічного подагричного артриту, за відсутності клінічних змін з боку ураженого суглоба, має місце підвищення місцевої температури, що вказує на наявність субклінічного запалення.

КЛючОВІ СЛОВА: хронічний подагричний артрит; термографія.

Вступ. В останні роки значно збільшився інтерес до вивчення подагри у зв'язку з високим їі поширенням та частим розвитком рецидивів, що призводить до тривалої втрати працездатності. Водночас немало питань її патогенезу залишаються нез'ясованими, а діагностика і лікування вимагають удосконалення [1, 2$]$.

Традиційно прийнято вважати, що ця хвороба уражає переважно чоловіків середнього віку, але в останні десятиліття зростає їі поширення серед пацієнтів старшої вікової групи, а також серед жінок, що пов'язують із збільшенням тривалості життя, наявністю хронічних захворювань, тривалим прийомом діуретиків, антикоагулянтів, низьких доз аспірину, зловживанням алкоголем тощо [3].

До важливих клініко-патогенетичних проявів подагри належать порушення терморегуляції та реґіонарного кровотоку. Тому новим перспективним методом дослідження $є$ термографія. Вона дає цінну інформацію про енергетичні процеси в органах і тканинах, внаслідок реєстрації природного інфрачервоного випромінювання.

Патологічні процеси, посилюючи або послаблюючи інфрачервоне випромінювання, можуть спричинити значні зміни термографічної карти- ни. За допомогою термографії можна виявити не тільки поверхневі, а й глибокі порушення, які, завдяки провідності інфрачервоних променів, «проектуються» на шкіру. Кожний хворий має свою теплову картину, яку потрібно інтерпретувати.

Належна оцінка термотопографії досліджуваної ділянки дозволяє визначити розподіл «гарячих» $\mathrm{i}$ «холодних» зон у зіставленні їх локалізації з розташуванням патологічного утвору, особливості контурів вогнища, його структуру та ділянки поширення. Кількісна оцінка проводиться для визначення показників різниці температур (градієнтів) зони ураження порівняно із симетричною зоною. Закінчують аналіз термограм математичною о6робкою зображення [4].

Основними перевагами термографічного дослідження $\epsilon$ відносно низька вартість, відсутність іонізуючого випромінювання чи електромагнітних полів, абсолютна неінвазивність, безпечність, відсутність протипоказань, можливість діагностування на ранніх стадіях захворювання до появи рентгенологічних або УЗД змін, можливість вибору послідовності нешкідливих дослідницьких процедур для вагітних жінок і дітей, а також одночасної оцінки функціонального стану різних систем організму (при оглядовій термографії) [5]. 
Огляди літератури, оригінальні дослідження, погляд на проблему, випадок з практики, короткі повідомлення

Метод термографії широко застосовують у різних галузях медицини: онкології, ангіології, акушерстві та гінекології, хірургії, урології, ортопедії й травматології, комбустіології, офтальмології, неврології, дерматології та багатьох інших спеціальностях [4].

Зокрема, є численні дослідження теплового малюнка при остеоартрозі, псоріатичному артриті, ревматоїдному артриті [6-10]. Проте термографічна картина при подагричному артриті залишається мало вивченою.

Мета дослідження - клініко-патогенетичне обґрунтування застосування термографії для розпізнавання хронічного подагричного артриту.

Матеріал і методи дослідження. У дослідження включено 40 пацієнтів з хронічним подагричним артритом (37 чоловіків і 3 жінки) віком від 45 до 74 років, які були госпіталізовані у ревмокардіологічне відділення КНП «Тернопільська комунальна міська лікарня № 2». Тривалість захворювання склала понад 5 років. Діагноз подагри верифіковано згідно з існуючими настановами і наказом МОЗ України № 676 від 12.10.2006 р. Усі хворі отримували лікування відповідно до протоколу: гіпоурикемічну терапію алопуринолом в дозі 200-300 мг/добу перорально, протизапальну та знеболювальну терапію. Контрольну групу склали 15 здорових осіб такого ж віку.

Пацієнти спрямовані в стаціонар у різні строки захворювання, більшість госпіталізовано у перші 4 дні від початку загострення хронічного подагричного артриту. Пізня госпіталізація була пов'язана з неефективним амбулаторним лікуванням.

Термографічне дослідження здійснювали за допомогою тепловізора ULIRvision TI 120 (Zhejiang Ulirvision Technology Co., Китай). Пацієнтів обстежували в умовах стаціонару в першій половині дня, при цьому хворий займав вертикальне, горизонтальне або сидяче положення залежно від його стану і локалізації ураження. Перед дослідженням протягом 25-30 хв тривала температурна адаптація шкіри досліджуваної ділянки до температури приміщення. Інтенсивність больового синдрому оцінювали за візуальною аналоговою шкалою болю (ВАШ).

Результати й обговорення. Легкий перебіг хронічного подагричного артриту діагностовано у 11 (27,5 \%) хворих, середній - у 23 (57,5 \%), тяжкий - у 6 (15\%). І рентгенологічна стадія виявлена у $17,5 \%$, II - у 55 \%, III - у 27,5 \%. Моноураження спостерігалося у 9 (22,5 \%), олігоураження - у 19 (47,5 \%), поліураження - у 12 (30\%) пацієнтів.

При госпіталізації основними скаргами всіх хворих були біль в уражених суглобах, значне обмеження рухів у них. При цьому рівень больових відчуттів знаходився в межах 30-95 мм і залежав від тривалості недуги, віку хворих. Зі зростанням тривалості захворювання збільшувалася кількість уражених суглобів, тофусів, посилювалася інтенсивність болю за ВАШ, збільшувалася частота загострень протягом року.

У нормі в здорових людей існують зони гіпері гіпотермії, але температурний градієнт симетричних відносно серединної лінії точок не перевищує 0,6 ${ }^{\circ} \mathrm{C}$.

У період загострення хронічного подагричного артриту всі хворі скаржилися на біль, обмеження рухів і набряклість ураженого суглоба, при запаленні тофусів - на виражену гіперемію та їх болючість. При цьому в 15 \% пацієнтів мало місце підвищення температури тіла до субфебрильних або фебрильних цифр. При об'єктивному огляді виявлено набряклість, дефігурацію і деформацію суглоба, шкіра над ним гаряча на дотик, рухи обмежені через виражену болючість.

При виписуванні зі стаціонару 27,5 \% пацієнтів скаржились на легкий біль в уражених суглобах, решта 72,5 \% ніяких скарг не мали. Візуальних змін не виявлено, рухи активні.

Через 1-3 місяці після виписування пацієнти не скаржилися на біль у суглобах, активні рухи в них були збережені.

Для ілюстрації наводимо короткий витяг із медичної карти стаціонарного хворого Н., 62 років, з діагнозом: хронічний подагричний артрит, поліартрит з переважним ураженням суглобів стоп, кистей. II рентгенологічна стадія I плеснофалангового суглоба, І рентгенологічна стадія суглобів кистей. ФНС I ст.

На термограмі (рис. 1, а), зробленій у розпал хвороби, в ділянці лівого I плеснофалангового суглоба видно зону інтенсивної гіпертермії, яка за розмірами перевищує видиму гіперемію, границі еритеми чіткі. $\Delta$ Т дорівнювала $4,6^{\circ} \mathrm{C}$. При огляді уражений суглоб набряклий, гарячий на дотик, рухи обмежені через біль.

На термограмі при виписці (рис. 1,6$)$ зона гіпертермії мала менші площу й інтенсивність, чіткість контурів втрачалася. $\Delta$ Т склала $2,4{ }^{\circ} \mathrm{C}$. При цьому пацієнт відчував легкий біль при ходьбі, об'єктивно - суглоб не змінений, шкіра звичайного кольору, тепла на дотик.

На знімку, зробленому через 2 місяці після виписування (рис. 1, в), спостерігається ділянка гіперемії невеликої інтенсивності над досліджуваним суглобом. $\triangle$ Т становить $0,7^{\circ} \mathrm{C}$. О6'єктивносуглоб не змінений, біль і обмеження рухів у ньому не турбували.

У 75 \% обстежених на подагру виявлено тофуси, з переважною локалізацією на вушних раковинах, пальцях кистей, ліктьових суглобах. У 
Огляди літератури, оригінальні дослідження, погляд на проблему, випадок з практики, короткі повідомлення
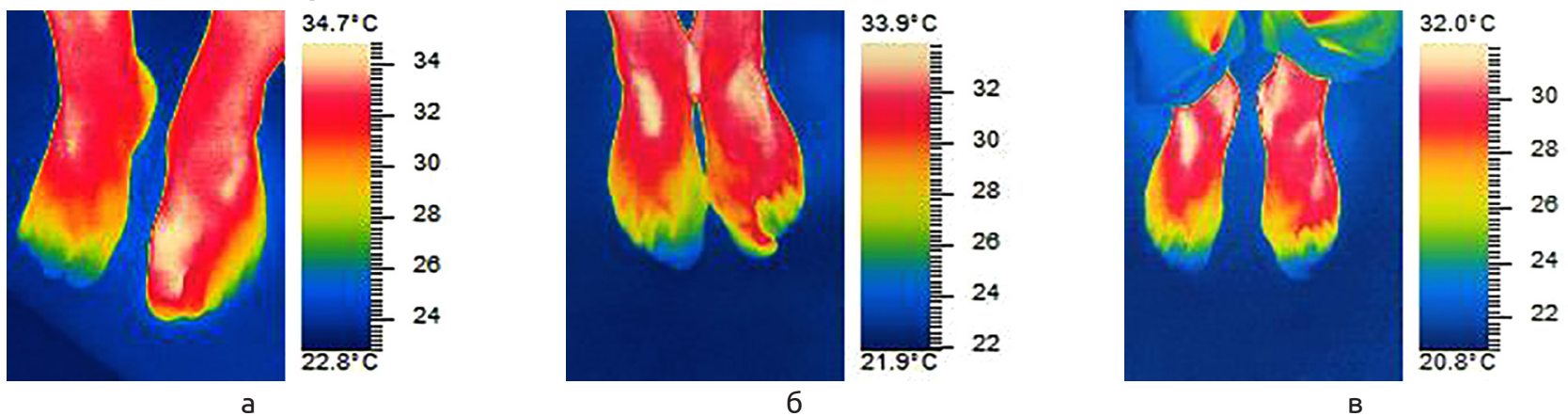

Рис. 1. Термограма хворого Н., 62 роки. Хронічний подагричний артрит, поліартрит з переважним ураженням суглобів стоп, кистей, II рентгенологічна стадія 1-го плеснофалангового суглоба, І рентгенологічна стадія суглобів кистей. ФНС І ст.: а - фаза загострення; 6 - при виписці; в - через 2 місяці після виписки.

16,7 \% з них загострення подагричного артриту перебігало з ознаками запалення тофусів (набряк, почервоніння, біль), у 83,3 \% - без ознак запалення.

Таким чином, вогнище гіпертермії на термограмі хворих з хронічним подагричним артритом відображає запальний процес в суглобі з властивим йому посиленням енергетичних процесів і тепловіддачі.

На формування теплового малюнка подагричного артриту значно впливає реакція мікросудинного русла у вогнищі запалення, внаслідок утворення у суглобі преципітату мікрокристалів уратів, що призводить до розвитку синовіїту. Переважною реакцією мікросудинного русла на ушкодження $\epsilon$ розширення судин. Розширюються артеріоли, збільшуються кількість функціонуючих капілярів та приплив крові до місця пошкодження, що спричиняє почервоніння ділянки запалення і підвищення локальної температури.

Розвитку цих змін сприяють як рефлекторні, так і гуморальні, метаболічні й нейропаралітичні фактори. Реакція судинного русла значною мірою пов'язана з виділенням вазоактивних медіаторів запалення (гістамін, серотонін, брадикінін, простагландини). Крім того, внаслідок порушення метаболізму накопичуються молочна кислота, аденозин, калій. Через дію пошкоджувальних факторів відбувається деструкція сполучної тканини, зменшення еластичності якої також сприяє розширенню судин $[11,12]$. У зв'язку з цим підвищується температура в ділянці запалення і тепло поступає на поверхню шкіри шляхом конвекції.

При хронічному подагричному артриті переважають явища проліферації, лімфоїдної інфільтрації синовіальної оболонки. Наявність кристалів уратів у синовіальній оболонці призводить до стимуляції хондроцитів з утворенням прозапальних цитокінів, оксиду азоту і матриксних металопротеїназ, що призводить до пошкодження хряща і проявляється хронічним синовіїтом $[13,14]$.

Висновки. 1. При подагричному артриті у фазі загострення наявне інтенсивне інфрачервоне випромінювання з ураженої ділянки. На термограмах воно проявляється термоасиметрією із зоною гіпертермії, яка перевищує площу запалення.

2. У фазі загострення подагричного артриту перепад радіаційної температури у вогнищі запалення, порівняно з симетричними здоровими ділянками шкіри, коливається від 1,8 до 5,4 ${ }^{\circ} \mathrm{C}$.

3. У період ремісії хронічного подагричного артриту за відсутності клінічних змін з боку ураженого суглоба має місце підвищення місцевої температури, що вказує на наявність субклінічного запалення.

\section{ЛІТЕРАТУРА}

1. Roddy E. Epidemiology of gout / E. Roddy, H. K. Choi / Rheum. Dis. Clin. North Am. - 2014. - No. 40 (2). - P. 155-175.

2. Ragab G. Gout: An old disease in new perspective: a review / G. Ragab, M. Elshahaly, T. J. Bardin // Adv. Res. 2017. - No. 8 (5). - P. 495-511.

3. Воробьев П. А. Подагра в гериатрической практике : методические рекомендации. Часть 1 / П. А. Воробьев, В. В Цурко, М. Е. Елисеева // Клиническая геронтология. - 2016. - Т. 22, № 3-4. - С. 3-9.
4. Андрейчин М. А. Дистанційна термографія та її значення для діагностики гострого тонзиліту / М. А. Андрейчин, В. С. Копча // Інфекційні хвороби. -2016. № 3. - С. $82-88$.

5. Дистанционная инфракрасная термография как современный неинвазивный метод диагностики заболеваний / Л. Г. Розенфельд, А. В. Самохин, Е. Ф. Венгер [и др.] // Украинский медицинский журнал. - 2008. № $6 .-$ C. 1-6. 
Огляди літератури, оригінальні дослідження, погляд на проблему, випадок з практики, короткі повідомлення

6. Assessment of hand osteoarthritis: correlation between thermographic and radiographic methods / G. Varjú, C. F. Pieper, J. B. Renner, V. B. Kraus // Rheumatology. - 2004. - Vol. 43, No. 7. - P. 915-919.

7. Automated analysis method for screening knee osteoarthritis using medical infrared thermography / Jin Chao, Yang Yang, Z.-J. Xue [et al.] // Journal of Medical and Biological Engineering. - 2013. - No. 33 (5). - P. 471-477.

8. Шушарин А. Г. Медицинское тепловидение современные возможности метода / А. Г. Шушарин, В. В. Морозов, М. П. Половинка // Современные проблемы науки и образования. - 2011. - № 4. - С. 1-18.

9. Применение инфракрасной термографии в современной медицине (обзор литературы) / И. С. Кожевникова, М. Н. Панков, А. В. Грибанов [и др.] // Экология человека. - 2017. - № 2. - С. 39-46.

10. Розробка та обґрунтування методики термографічного дослідження для ранньої діагностики псоріатичного артриту у хворих з ураженням суглобів кисті /
О. А. Бур'янов, А. В. Самохін, В. П. Кваша, В. В. Котюк // Літопис травматології та ортопедії. - 2009. - № 1-2. С. $115-119$.

11. Свінціцький А. С. Діагностика та лікування ревматичних захворювань : навчальний посібник / А. С. Свінціцький. - К. : Видавничий дім «Медкнига», 2017. -372 c.

12. Запалення - типовий патологічний процес / М. С. Регеда, Т. С. Бойчук, Ю. І. Бондаренко, М. М. Регеда. - Вид. друге, доп. та перер. - Львів, 2013. - 148 с.

13. Schiavenato $M$. Thermography detects subclinical inflammation in chronic tophaceous gout / M. Schiavenato, R. G. Thiele // The Journal of Rheumatology. - 2012. Vol. 39, No. 1. - P. 182-183.

14. Characteristics of the first metatarsophalangeal joint in gout and asymptomatic hyperuricaemia: a crosssectional observational study / S. Stewart, N. Dalbeth, A. C. Vandal, K. Rome // Journal of Foot and Ankle Research. - 2015. - Vol. 8, No. 1. - P. 41.

\section{REFERENCES}

1. Roddy, E., \& Choi, H. K. (2014). Epidemiology of gout. Rheumatic Disease Clinics, 40 (2), 155-175.

2. Ragab, G., Elshahaly, M., \& Bardin, T. (2017). Gout: an old disease in new perspective - a review. Journal of Advanced Research, 8 (5), 495-511.

3. Vorobyev, P.A., Tsurko, V.V., \& Yeliseyeva, M.Ye. (2016). Podagra v geriatricheskoy praktike (Metodicheskiye rekomendatsii. Chast 1) [Gout in geriatric practice (Methodical recommendations. Part 1)]. Klinicheskaya gerontologiya - Clinical Gerontology, 22 (3-4), 3-9 [in Russian].

4. Andreichyn, M.A., \& Kopcha, S.V. (2016). Dystantsiina termohrafiia ta ii znachennia dlia diahnostyky hostroho tonzylitu [Remote thermography and its significance for the diagnosis of acute tonsillitis]. Infektsiini khvoroby Infectious Diseases, (3), 82-88 [in Ukrainian].

5. Rozenfeld, L.G., Samokhin, A.V., Venger, Ye.F., Loboda, T.V., Kolotilov, N.N., Kollyukh, A.G., \& Dunaevsky, V.I. (2008). Distantsionnaya infrakrasnaya termografiya kak sovremennyy neinvazivnyy metod diagnostiky zabolevaniy [Remote infrared thermography as a modern non-invasive method for diagnosing diseases]. Ukrainskiy meditsinskiy zhurnal - Ukrainian Medical Journal, 6 (68), 92-97 [in Russian].

6. Varju, G., Pieper, C. F., Renner, J. B., \& Kraus, V. B. (2004). Assessment of hand osteoarthritis: correlation between thermographic and radiographic methods. Rheumatology, 43 (7), 915-919.

7. Jin, C., Yang, Y., Xue, Z.J., Liu, K.M., \& Liu, J. (2013). Automated analysis method for screening knee osteoarthritis using medical infrared thermography. Journal of Medical and Biological Engineering, 33 (5), 471-477.

8. Shusharin, A.G., Morozov, V.V., \& Polovinka, M.P. (2011). Meditsinskoe teplovidenie - sovremennye vozmozhnosti metoda [Medical thermal imaging - modern

possibilities of the method]. Sovremennye problemy nauki $i$ obrazovaniya - Modern Problems of Science and Education, 4, 1-18 [in Russian].

9. Kozhevnikova, I.S., Pankov, M.N., Gribanov, A.V., Startseva, L.F., \& Ermoshyna, N.A. (2017). Primenenie infrakrasnoy termografii v sovremennoy meditsine (obzor literatury) [The use of infrared thermography in modern medicine (literature review)]. Ekologiya cheloveka - Human Ecology, 2, 39-46 [in Russian].

10. Buryanov, O.A., Samockhin, A.V., Kvasha, V.P., \& Kotiuk, V.V. (2009). Rozrobka ta obhruntuvannia metodyky termohrafichnoho doslidzhennia dlia rannoi diahnostyky psoriatychnoho artrytu u khvorykh z urazhenniam suhlobiv kysti [Development and substantiation of the method of thermographic research for the early diagnosis of psoriatic arthritis in patients with lesion of the joints of the brush]. Litopys travmatolohii ta ortopedii - Chronicle of Traumatology and Orthopedics, 10 (4), 380-385 [in Ukrainian].

11. Svintsitskyi, A.S. (2017). Diahnostyka ta likuvannia revmatychnykh zakhvoriuvan: navchalnyi posibnyk [Diagnosis and treatment of rheumatic diseases: manual]. Kyiv: "Vydavnychyi dim Medknyha" [in Ukrainian].

12. Reheda, M.S., Boichuk, T.M., \& Bondarenko, Yu.I. (2013). Zapalennia-typovyi patolohichnyi protses. Monohrafiia [Inflammation - typical pathological process. Monograph]. Lviv: Korpan [in Ukrainian].

13. Schiavenato, M., \& Thiele, R.G. (2012). Thermography detects subclinical inflammation in chronic tophaceous gout. The Journal of Rheumatology, 39 (1), 182-183.

14. Stewart, S., Dalbeth, N., Vandal, A. C., \& Rome, K. (2015). Characteristics of the first metatarsophalangeal joint in gout and asymptomatic hyperuricaemia: a crosssectional observational study. Journal of Foot and Ankle Research, 8 (1), 41. 


\section{○С. М. Андрейчин, У. О. Мудра, Т. Ю. Чернец}

Тернопольский национальный медицинский университет имени И. Я. Горбачевского МОз Украины

РЕЗЮМЕ. В последние годы значительно повысился интерес к изучению подагры в связи с высоким уровнем заболеваемости и частыми рецидивами, что приводит к длительной потере трудоспособности. К важным клинико-патогенетическим проявлениям подагры относят нарушения терморегуляции и регионарного кровотока. Однако термография подагрического артрита остается мало изученной.

Цель исследования - клинико-патогенетическое обоснование возможного применения термографии для распознавания хронического подагрического артрита.

Материал и методы. В исследование включено 40 стационарных пациентов с хроническим подагрическим артритом (37 мужчин и 3 женщины) в возрасте от 45 до 74 лет. Длительность заболевания составила более 5 лет. Термографическое исследование осуществляли с помощью тепловизора ULIRvision TE 120 (Zhejiang Ulirvision Technology (о., Китай), следуя рекомендациям производителя.

Результаты. Установили, что с ростом продолжительности заболевания имеет место увеличение числа пораженных суставов, тофусов, усиление интенсивности боли по ВАШ, частоты обострений в течение года. На термограммах, полученных в фазе обострения хронического подагрического артрита, видно зону интенсивной гипертермии, которая по размерам превышала видимую гиперемию. Границы эритемы четкие. $\Delta \mathrm{T}^{\mathrm{T}}$ равна $1,8-5,4^{\circ} \mathrm{C}$. У реконвалесцентов при выписке из стационара зона гипертермии была меньшей площади и интенсивности, четкость контуров терялась. $\Delta$ Т составила $0,7-3,3^{\circ} \mathrm{C}$. Через 2 месяца после выписки у большинства больных сохранялась гипертермия небольшой интенсивности над исследуемым суставом. $\Delta$ T составляла $0,6-1{ }^{\circ} \mathrm{C}$.

Выводы. При подагрическом артрите в фазе обострения имеет место интенсивное инфракрасное излучение с пораженного участка. На термограммах оно проявляется термоасимметрией с зоной гипертермии, которая превышает площадь воспаления. В фазе обострения данного заболевания перепад радиационной температуры в очаге воспаления, по сравнению с симметричными здоровыми участками кожи, колеблется от 1,8 до $5,4{ }^{\circ} \mathrm{C}$. В период ремиссии хронического подагрического артрита при отсутствии клинических изменений со стороны пораженного сустава имеет место повышение местной температуры, что указывает на наличие субклинического воспаления.

КЛЮЧЕВЫЕ СЛОВА: хронический подагрический артрит; термография.

\section{CLINICAL SIGNIFICANCE OF THERMOGRAPHY AT CHRONIC GOUTY ARTHRITIS}

\section{○S. M. Andreychyn, U. O. Mudra, T. Yu. Chernets}

\section{Horbachevsky Ternopil National Medical University}

SUMMARY. In recent years, interest in the study of gout has increased significantly due to the high level of its morbidity and frequent relapses, which leads to prolonged disability. Important clinical and pathogenetic manifestations of gout include violation of thermoregulation and regional blood flow. However, the thermography of gouty arthritis remains little studied.

The aim of the study - the clinical and pathogenetic reasoning of the possible application of thermography for the diagnosis of chronic gouty arthritis.

Materials and Methods. The study included 40 stationary patients with chronic gouty arthritis (37 men and 3 women) aged 45 to 74 years. The duration of the disease was more than 5 years. The thermographic examination was performed using the ULIRvision TI 120 thermal imager (Zhejiang Ulirvision Technology Co., China), following the manufacturer's recommendations.

Results. It was established that with an increase of the disease duration there is an increase in the number of affected joints, tofus, increased intensity of pain for VAS, the frequency of exacerbations during the year. On the thermograms obtained in the phase of exacerbation of chronic gouty arthritis, a zone of intense hyperthermia, which in size exceeded the apparent hyperemia, was visible. Borders of erythema are clear. $\Delta \mathrm{T}$ was $1.8-5.4^{\circ} \mathrm{C}$. In reconvalescents at discharge from the hospital, the area of hyperthermia smaller and less intense, the contours were not clear. $\Delta T$ was $0.7-3.3^{\circ} \mathrm{C}$. Two months after discharge, most patients had hyperthermia at low intensity over the studied joint. $\Delta T$ was $0.6-1^{\circ} \mathrm{C}$.

Conclusions. In gouty arthritis in the exacerbation phase there is intense infrared radiation from the affected area. On thermograms, it manifests itself as a thermal asymmetry with a zone of hyperthermia that exceeds the area of inflammation. In the phase of exacerbation of this disease, the change in the radiation temperature in the inflammation center, as compared with symmetrical healthy parts of the skin varies from 1.8 to $5.4{ }^{\circ} \mathrm{C}$. In the period of remission of chronic gouty arthritis, in the absence of clinical changes from the affected joint, there is an increase in the local temperature, indicating the presence of subclinical inflammation.

KEY WORDS: chronic gouty arthritis; thermography. 